\title{
慢性腎不全患者の透析期間別にみた細胞性免疫能
}

\author{
大園恵幸村谷良昭川冨正弘平井義修 \\ 原田孝司原耕平田浦幸 - * 松尾 新一郎* \\ 広 瀬 健 ${ }^{* *}$ 松 隈 玄一郎** 船 越 衛 - ** \\ 長崎大学第 2 内科 長崎市立成人病センター* 桜町クリニック** \\ (昭和 63 年 4 月 18 日受付)
}

key words : chronic hemodialysis patients, cell mediated immunity, $\mathrm{T}$ cell subset, $\mathrm{T}$ cell function, tuberculosis

〈要旨〉

透析中の慢性腎不全患者 46 名について細胞性免疫能の検討を行った. 細胞性免疫能については, 末梢血リンパ球数, T cell および B cell の百分率, ツベルクリン反応, PHA 幼若化反応, T cell subset, T cell function などについて透 析期間別（導入期, 維持透析 5 年未満および 5 年以上）について検討した。

透析患者の末梢リンパ球数, ツベルクリン反応, PHA 幼若化反応の低下および T cell subset の異常を認めた.

透析期間別では, 特に導入期にツベルクリン反応, T cell function などの低下を示し, 維持透析期にはとれらの免 疫能は回復傾向にあり，5年以上の長期透析例は再び低下傾向にあった. 細胞性免疫能が関与する感染症でとくに結 核症は透析導入期および長期透析時に留意すべきと考えられた。

\section{Cell-mediated immunity in chronic hemodialysis patients in relation to the period of dialysis.}

Yoshiyuki Ozono, M. D., Yoshiaki Muraya, M. D., Masahiro Kawatomi, M. D., Yoshinobu Hirai, M. D., Takashi Harada, M. D., Kohei Hara, M. D., Koichi Taura, M. D., Shinichiro Mastuo M. D.*, Takeshi Hirose, M. D.**, Genichiro Mastukuma, M. D.**, Morikazu Funakoshi M. D.**

Second Department of Internal Medicine, Nagasaki University, Nagasaki Municipal Adult Disease Center* Sakuramati Clinic**, Nagasaki

We investigated cell-mediated immunity in dialysis patients. The data indicated that dialysis patients have lymphopenia, decreased reaction of PPD and decreased blastoid formation of PHA.

PPD reaction and T-cell function decreased in the early stage of dialysis and improved in the stage of maintenance dialysis, then subsequently decreased again in the long-term stage of dialysis.

These data suggests that patiens on dialysis have decreased immunologic host defense in the early and long -term stages of dialysis.

\section{はじめに}

血液透析をうけている慢性腎不全患者においては, 肺 結核などの感染症に罹患しやすい事が指摘されている. その原因として兔疫能の低下が問題となっており ${ }^{1,2)}$, 特 に細胞性免疫能の低下を指摘する報告が多いようであ $ろ^{3,4)}$. 今回我々は, 慢性腎不全患者の細胞性免疫能につ いて T cell subset や T cell function などを中心に検討 を行った。また, 透析期間や透析導入が T cell などの細 胞性免疫に如何に影響を与えているかについても検討し

大園 恵幸 長崎大学第 2 内科

于 852 長崎市坂本町 12-4（0958-47-2111）
たので，その成績について報告する．

\section{対象}

長崎大学第 2 内科およびその関連病院にて透析中の患 者 643 名を対象として, 結核症の発症と, うち 165 名に はリンパ球数, 46 名には $\mathrm{T}$ 細胞, B 細胞, $\mathrm{T}$ 細胞サブセッ 卜, PHA 幼若化およびT細胞ヘルパー活性について検 討した。 その 46 名の内訳は, 導入期 10 名（透析開始よ り 3 か月まで), 維持透析 36 名 ( 5 年末満 20 名, 5 年以 上 16 名）であり透析前 8 名（血清クレアチニン $8 \mathrm{mg} / \mathrm{d} l$ 以上）正常人 20 名をコントロールとした。 


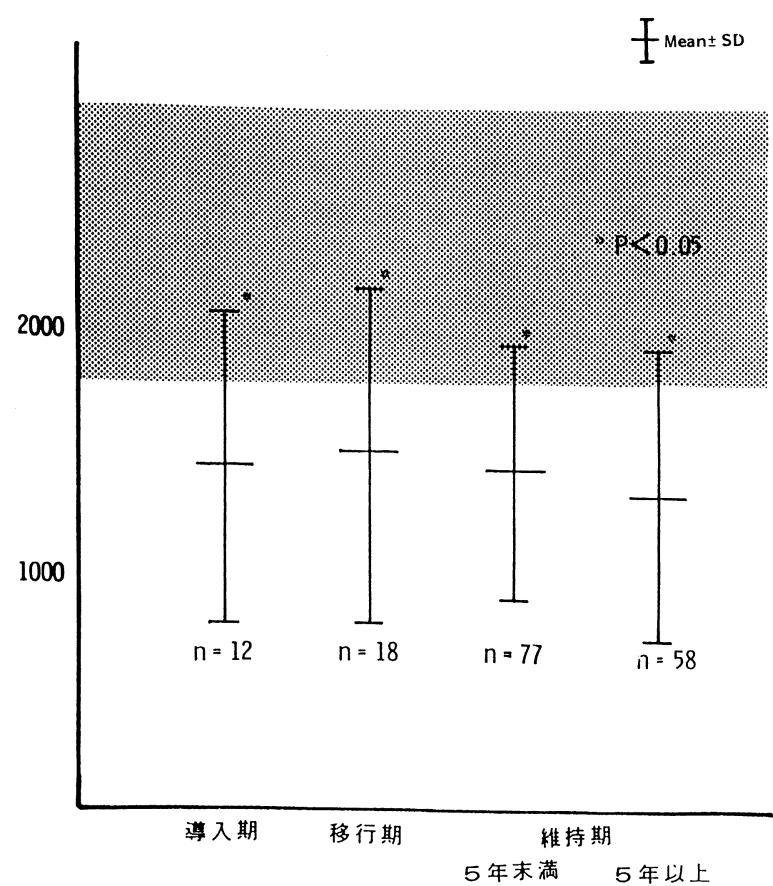

図 1 透析患者のリンパ球数

\section{方法}

検索は末梢血のリンパ球数， T cell および B cell の 百分率, 遅延型過敏反応としてツベルクリン反応, PHA 幼若化反応, $\mathrm{T}$ cell subset, $\mathrm{T}$ cell function などについ て，透析期間別に検討した。

1 ) 末梢リンパ球数：早朝空腹時に採血して測定した。

2) T cell および B cell の subpopulation : Ficoll Conray 比重遠心法にてリンパ球を分離した後, 羊赤血 球（E）ロゼット形成細胞を T cell および $\mathrm{EAC}$ 結合細 胞を B cell として， T cell および B cell の百分率を検 討した。

3 ）ツベルクリン反応：ツベルクリン一般診断用液 0 . $05 \mu \mathrm{g} / 0.1 \mathrm{~m} l$ PPD を使用し, 右前腕屈測に皮内注射して 48 時間後に判定し, 結果はツベルクリン判定基準に従っ た.

4) PHA 幼若化反応：Ficoll 比重遠心法にて分離し たリンパ球 $5 \times 10^{5} / \mathrm{m} l$ に PHA $10 \mu l$ を加え, マイクロ プレートを使用し $37^{\circ} \mathrm{C} 5 \% \quad \mathrm{CO}_{2}$ インキュベーター内で 3 日間培養した後, ハーベスト 16 時間前に $0.25 \mu \mathrm{Ci}{ }^{3} \mathrm{H}$ thymidine を加え, auto cell harvester で測定した.

5 ) T cell subset：モノクローナル抗体 OKT series を用いリンパ球をインキュベートし,リンパ球 10,000 個 のうちの OKT3, OKT4, OKT8 陽性細胞数を測定し, 百分率で判定した。

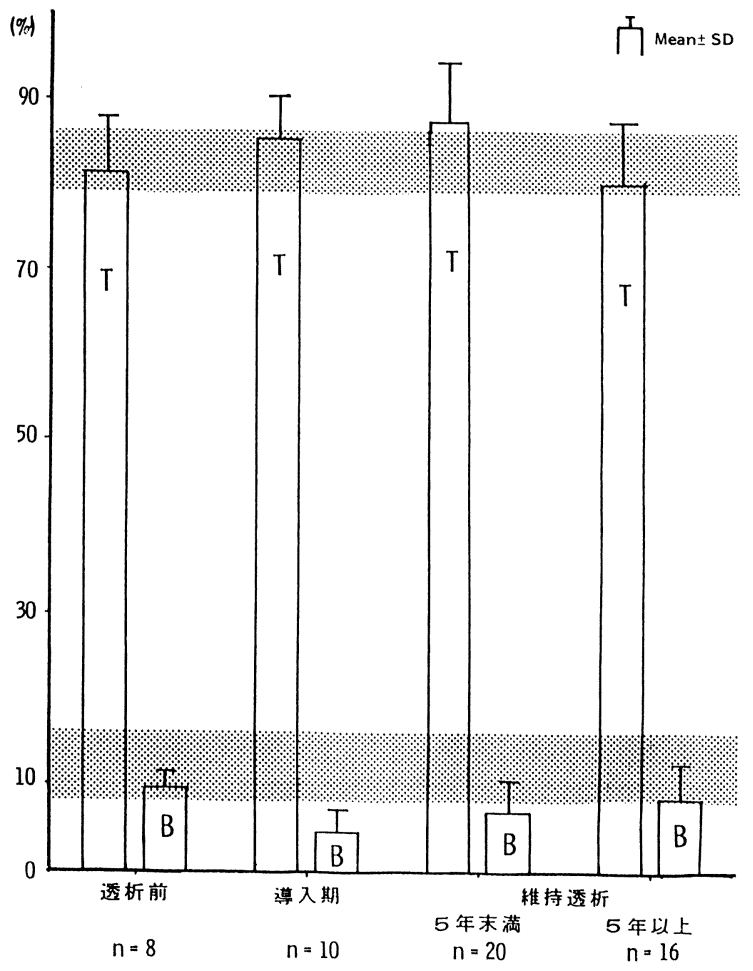

図 2 透析患者の $\mathrm{T}$. B cell 百分率

6) $\mathrm{T}$ cell function: $\mathrm{T}$ cell helper function は矢田 ら 5 の方法に準じ，T cell $5 \times 10^{5}$ に B cell $1 \times 10^{5}$ および PWM $10 \mu \mathrm{g}$ を加え, $10 \%$ FCS 加 RPMI の培養液中で $5 \% \mathrm{CO}_{2}$ インキュベーター内で培養し, 上清の $\mathrm{IgG}$ を 測定し，コントロールとの比で測定した。

\section{成績}

1. 末梢血リンパ球数

透析患者 165 例の末梢血リンパ球数は図 1 のごとく, 導入期, 1 年末満の移行期, 5 年末満および 5 年のいず れの時期においてもリンパ球数の減少を認めたが, 各群 間の差異は認めなかった。

2. T cell および B cell 百分率

1) $\mathrm{T}$ cell 百分率：透析前 $84.6 \% \pm 11.2 \%$, 導入期 $85.5 \% \pm 10.3 \%$, 維持期 5 年末満 $87.5 \pm 10.3 \% ， 5$ 年以 上 $80.5 \pm 13.0 \%$ であり, 各群において有意の差を認めな かった（図2).

2) B cell 百分率: 透析前 $9.2 \pm 1.6 \%$, 導入期 $4.9 \pm$ $1.8 \%$ であり, 維持期 5 年末満 $6.8 \pm 1.4 \%, 5$ 年以上 $8.5 \pm 1.2 \%$ であり, 透析導入時期に B cell の百分率は減 少するものと思われた（図 2 ).

3.ツベルクリン反応

ツベルクリン反応は, 透析導入後 46 名中 21 名 $(46 \%)$ 


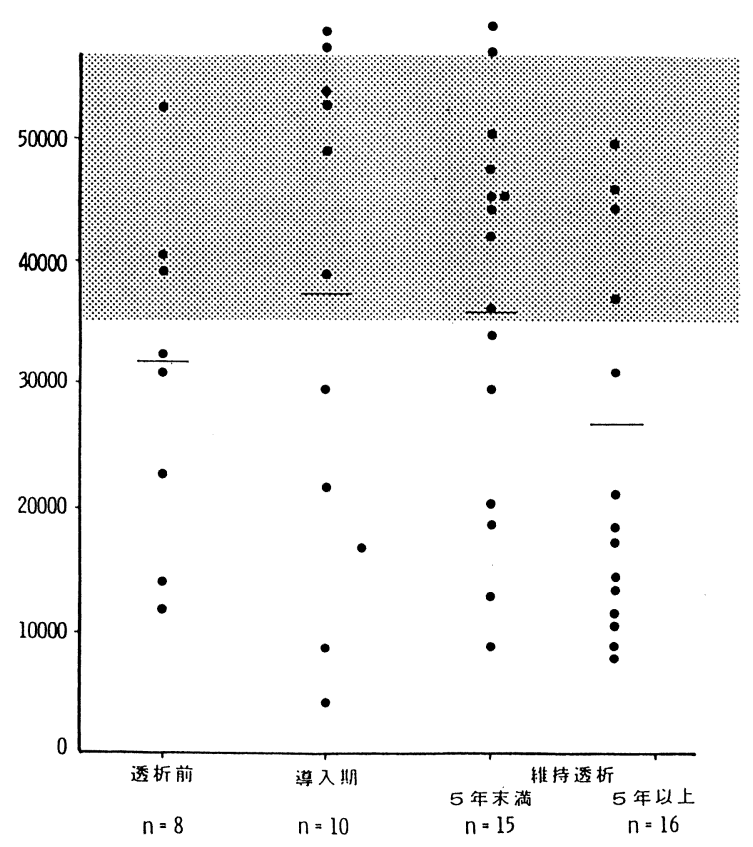

図 3 透析患者の PHA 幼若化反応

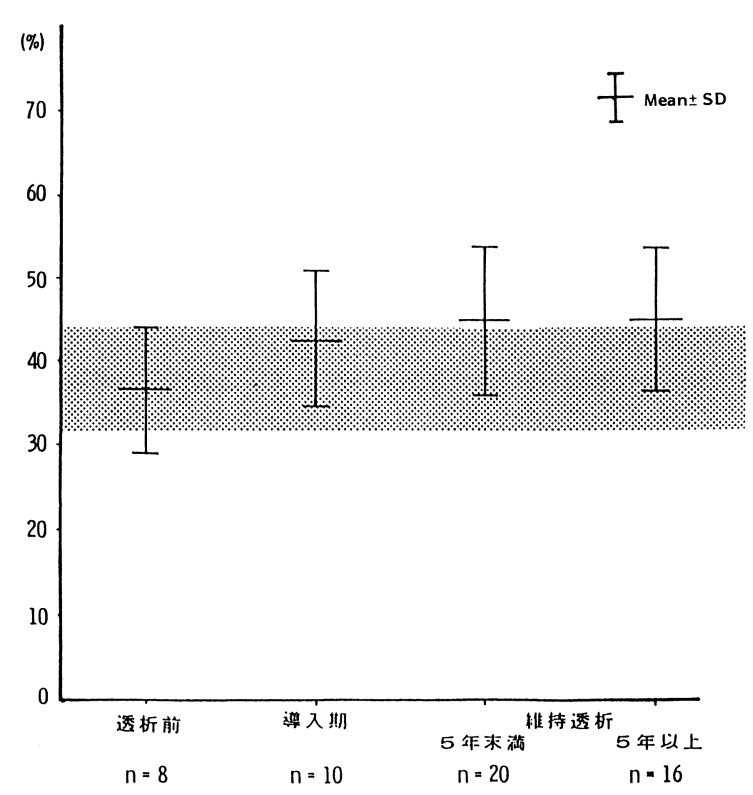

図 4 透析患者の $\mathrm{T}$ cell subset (OKT 4, helper $\mathrm{T}$ cell)

が低下していた. 特に透析前および 5 年以上の維持期に おいて低下していた。

4. T cell subset

1 ) 末梢血の OKT3 (whole T cell) 陽性細胞数 : 透

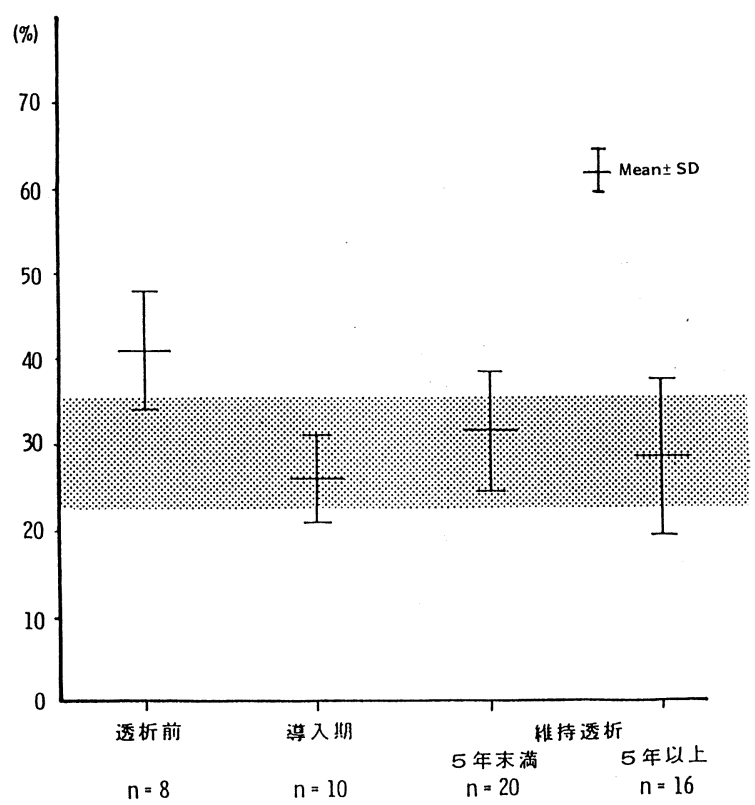

図 5 透析患者の $\mathrm{T}$ cell subset (OKT 8, supressor $\mathrm{T}$ cell)

析前 $74.0 \pm 6.0 \%$, 導入期 $69.0 \pm 6.2 \%$, 維持期 5 年末満 $75.8 \pm 7.3 \%, 5$ 年以上 $71.8 \pm 12.1 \%$ であり, 各群間では 有意の差を認めなかった。

2) OKT4 (helper/inducer T cell) 陽性細胞数：透 析患者では, $44.2 \pm 9.1 \%$ と正常コントロールの $37.5 \pm$ $7.7 \%$ に比し有意の差を認めなかった。透析群では（図 $4)$, 透析前 $36.6 \pm 7.97 \%$, 導入期 $42.6 \pm 8.1 \%$, 維持期 5 年末満 $44.8 \pm 8.8 \%, 5$ 年以上 $44.9 \pm 9.7 \%$ とKT4 陽性細胞数は, 透析前に比べて透析後に増加する傾向に あった。

3 ) OKT8 (supressor/cytotoxic T cell) 陽性細胞 数：図 5 に示したごとく, 透析患者で $30.5 \pm 7.2 \%$ と ントロール $29.0 \pm 6.5 \%$ に比べ有意の差を認めなかっ た. 各群間では, 透析前 $40.9 \pm 7.2 \%$, 導入期 $25.8 \pm$ $4.8 \%$, 維持期 5 年末満 $31.4 \pm 7.1 \%, 5$ 年以上 $28.4 \pm$ $8.9 \%$ と, OKT8 陽性細胞数は透析前で有意に（ $\mathrm{p}<$ 0.01）高く, 透析後の各時期で正常化していた。

5. T cell helper activity

透析患者では $1.01 \pm 0.46 \%$, 正常コントロール $1.25 \pm 0.35 \%$ に比べ有意差を認めなかった。しいし, 図 6 に示したごとく個々の症例をみると 46 名中 19 名が減 少していた。各群間では透析前 $0.82 \pm 0.28 \%$, 導入期 $0.71 \pm 0.27 \%$, 維持期 5 年末満 $1.07 \pm 0.55 \%, 5$ 年以上 $1.24 \pm 0.47 \%$ と $\mathrm{T}$ cell helper activity は導入期および 透析前に低い傾向にあった。 


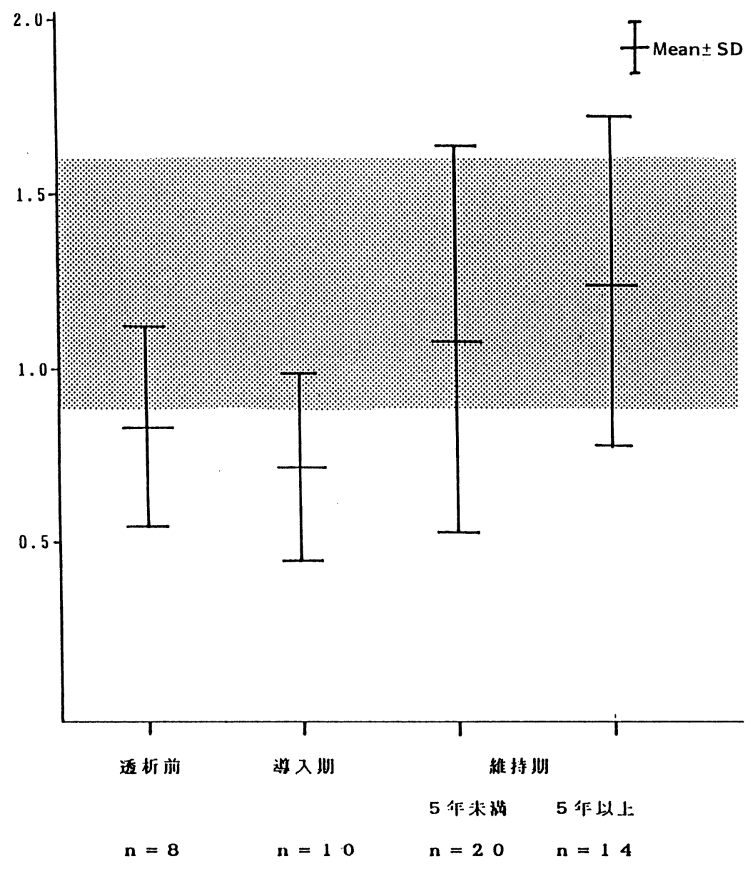

図 6 T cell helper activity

\section{6. 透析期間別の結核発生数}

結核症の発症数は, 今回調查対象とした維持透析患者 643 例中 35 例に発症を認め, その発生率を透析期間別に みてみると図 7 のごとく, 導入期および 1 年末満の移行 期には, 19 例 $(54.3 \%)$ と, 維持期 5 年末満の 10 例 $(28.6 \%)$ や 5 年以上の 6 例 $(17.1 \%)$ に比し, 結核の発 生率が有意に（ $\mathrm{p}<0.01 ）$ 高かった。

\section{考案}

慢性腎不全患者の細胞性免疫能の検討については数多 く報告されているが6,7), 我々は透析前と透析後のリンパ 球機能，とくに T cell subsetや T cell function などを 中心に透析期間別に検討を行った。 まず透析患者のリン パ球数を検討したところ, 正常群に比し有意に低下して いた. その原因として, 透析前および透析後も低下して いたことから, uremia による低栄養状態や uremic toxin によるリンパ球への影響や透析膜への付着などが 考えられた。次にリンパ球を $\mathrm{T}$ cell および B cell の百 分率でみたところ, B cell の百分率が透析導入後低下し ており, dialyzer への B cell の付着や透析施行による T cell の回復などが考えられた.

Kauffman ら ${ }^{8)} \mathrm{T}$ cell 百分率は正常であり, B cell の百分率は対照群にくらべて減少していたと報告してい る. 一方, ツベルクリン反応や PHA 幼若化についても 低下しているという報告がみられる ${ }^{9,10)}$. 我々の成績で

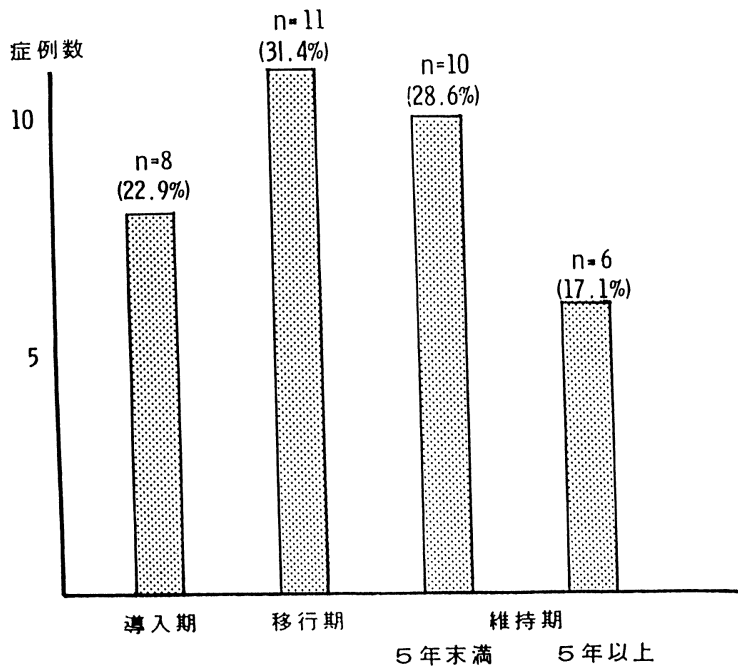

図 7 結核発症と透析期間

は，ツベルクリン反応は低下していたが期間別の差は認 められず，腎不全による遅延型過敏反応の低下が考えら れた. PHA 幼若化反応は透析前には低下を認めたが, 透 析後やや回復しており, 透析による適切な栄養状態の回 復や azotemia の改善などが考えられた. しかし，透析 を 5 年以上行うと再び低下しており, 長期透析では何等 かの別の要因が加わって低下するものと考えられた。

次に T cell の subset をモノクローナル抗体である OKT series でみてみると, OKT3 陽性細胞数は透析前 と後では変化なく, 正常範囲内であった. しかし OKT4 陽性細胞数は，透析前では減少しており，むしろ OKT8 陽性細胞数の著明な増加がみられた。しかし, 透析導入 とともに T cell subset は維持期にかけて次第に回復し ていた。透析前の OKT8 (suppressor T cell) 陽性細胞 数の増加の意味については不明であるが, suppressor T cell の増加とすれば，何らかの免疫反応の異常を抑制し ようとする機転が働いているのかもしれない.しかし， 透析導入によって $\mathrm{T}$ cell subset の変化が認められ, 特 に OKT4/OKT8 の比が正常化しているところから， azotemia や栄養状態の改善, dialyzer への T-cell の選 択的付着が影響していることが考えられた。

次に T cell helper activity については, 透析患者と 正常人との間には有意の差は認められなかったが，個々 の症例についてみてみると 46 例中 19 例が低下してい た。また期間別にみると，透析前および導入期に低下し ている傾向にあった。このことは T cell subset の結果 と考えあわせると, 透析による T cell への影響が強いた めと考えられた。 
以上のことから，透析患者の細胞性免疫能の低下は， ツベルクリン反応や PHA 幼若化反応などの遅延型反応 の低下とリンパ球とくに T cell の変化が認められた。透 析期間別にみてみると, 透析前の細胞性免疫能の状態と 透析導入期および維持期とでは異なる状態であった。透 析患者で結核の発症が多いことについてはすでに我々が 報告した ${ }^{11}$ がそれによると結核の感染率が透析患者では 高く透析期間別にみると導入期に最も発生率が高かっ た。このことは，今回の結果からみても，導入期に遅延 型過敏反応や $\mathrm{T}$ cell の変化が強いことと関連あるもの と考えられた。透析患者においては, 導入期に結核を含 めた感染症の発症に十分留意する必要があるものと思わ れた.

\section{まとめ}

透析患者の免疫能を検討したところ，末梢血のリンパ 球数, ツベルクリン反応, PHA 幼若化反応などの低下お よび T cell subset の異常を認めた。透析期間別にみる と，とくに導入期にツベルクリン反応， T cell function などの低下を示し, 維持期にはそれらの免疫能は回復傾 向にあったが， 5 年以上の長期透析時には同様に注意す べきことを強調したい.

\section{文献}

1）稲本 元：尿毒症における免疫不全と結核症. 透析 会誌 $12: 21-36,1979$

2）上田 泰，斉藤 篤：我が国に扔ける腎不全患者の 合併症の現況，日医新報 $2715: 31-34 ， 1976$

3）宮沢修三：透析患者の細胞性免疫一未梢血リンパ球 subpopulation の側面から一透析会誌 $12: 630-659$, 1977
4) Huber H, Pastner D, Dittrich P, Baunsteiner $\mathrm{H}$; In vitro reactivity of human lymphocyte in uremia. A comparison on with the impairment of delayed hypersensitivity. Clin Exp Immunol $5: 75$ $-82,1969$

5）矢田純一：ヒト T細胞における免疫グロブリン産生 能ないし Suppressor 能測定法の工夫. アレルギー 26:17-19, 1977

6) Rolley, RT ; Cell mediated immunity in patients on long term hemodialysis. Clin Exp Immunol $22: 54-62,1973$

7）稲本 元, 猪芳 亮: Uremic toxin の影響一腎不全 に打ける免疫不全. 最新医学 $31: 1730-1743 ， 1976$

8) Kauffman CA, Manzler AD, Phair JP : Cellmediated immunity in patients on long term hemodialysis. Clin Immunol $22: 54-61,1975$

9）稲本 元，猪芳 亮，稲本伸子：腎不全における免 疫不全一PPD による遅延型過敏反応の低下一臨床 免疫 $9: 269-274,1971$

10）早原信行：末期腎不全患者の免疫機能に関する研 究. 日本泌尿会誌 $64: 615-628,1973$

11）原田孝司, 村谷良昭, 松尾新一郎, 大園恵幸, 浦 繁 郎, 川冨正弘, 柴田哲雄, 平井義修, 横山一章, 荒 谷康弘, 原 耕平, 草場泰之, 進藤和彦, 斎藤 泰, 緒方弘文, 藤松真一郎, 徳永 毅, 新里 健, 田浦 幸一, 石川 寿, 広瀬 健, 松隈玄一郎, 船越衛一： 透析患者に発症した結核症. 腎と透析 $12: 97-102$, 1982 